\title{
What Are the Leveraging Factors of Public Service Innovation?
}

\author{
Rusmiyati \\ Institut Pemerintahan Dalam Negeri, Indonesia \\ E-mail: rusmiyatislukman@yahoo.co.id
}

Received: Oct.14, 2020 Accepted: Nov. 3, 2020 Online published: Nov. 18, 2020

doi:10.5296/jpag.v10i4.17818ＵRL: https://doi.org/10.5296/jpag.v10i4.17818

\begin{abstract}
This study aims to describe and analyze and interpret 1) the role of DPMPTSP in realizing innovative licensing and non-licensing services in Depok City; 2) The role of planning, leadership, human resources apparatus, and organizational culture; and 3) DPMPTSP's strategy for licensing and non- licensing service innovation in Depok City, West Java Province. As for the theory used to uncover the problems in this study, the theory of public service innovation developed by Rachel Asworth and friends as stated in the framework of thought (Ashworth, 2010). Through a qualitative method with a descriptive approach with a spiral analysis model by John W. Creswell, it was found that 1) the organizational environment, both internal and external DPMPTSP plays a role in the innovation of public services in Depok City; 2) The role of planning, leadership, apparatus human resources, and organizational culture that is built on DPMPTSP is a force to realize Public Service Innovation in Depok City; and 3) Strategy through an internal and external collaboration of local government and organizational learning is the trigger for realizing public service innovation in Depok City, West Java Province.
\end{abstract}

Keywords: regulation, planning, leadership, organizational culture

\section{Introduction}

The obligations and rights of the community to the quality of public services are a mandate in the law that must be guided in carrying out the duties of public services, especially those in direct contact with the community using public services. Public Service Principles should be a guideline that must be upheld for public service providers. This is intended so that there is no bias in the implementation of public services for service personnel who provide services to the community. For this reason, the second part of the Principles of Public Service Implementation is emphasized by the Principles, namely:

a. Public interest, b. legal certainty, c. equal rights, d. professionalism; e. Participative, f. 
equal treatment / non-discrimination; g. transparent, h. accountability; i. facilities and special treatment for vulnerable groups, y. timeliness and speed, and k. convenience, and affordability (Chen et al., 2020).

Quality public services provided to the public are carried out based on the obligations of Public Service Providers as emphasized in Article 15 of Law Number 25 of 2009 concerning Public Services, which are the obligations of the Provider, namely:

The Operator is obliged to: a. compile and set service standards; b. compile, stipulate, and publish service announcements; c. placing competent executors; d. provide facilities, infrastructure and / or Public Service facilities that support the creation of an adequate service climate; e. provide quality services in accordance with the principles of public service delivery; f. carry out services in accordance with service standards; $g$. Actively participating and complying with laws and regulations related to the provision of Public Services; h. provide accountability for the services provided; i. assist communities in understanding their rights and responsibilities; $j$. Responsible for the management of the public service organizing organization; $\mathrm{k}$. give an accountability in accordance with applicable law when resigning or releasing responsibility for a position or position; and l. fulfill summons or represent an organization to attend or carry out an order for a legal action at the request of an authorized official from a state institution or government agency that is entitled, authorized and legally in accordance with statutory regulations.

Implementation of Public Services as referred to in Article 15 of Law Number 25 of 2009 is intended so that the Public Service Providers realize that in addition to Service Providers having rights in Public Service Delivery, there are also obligations that must be fulfilled. For service units that have conducive conditions as well as play a role in building and developing innovation, it is necessary to get appreciation in addition to acknowledging the innovations that have been made, as well as motivating other Public Service Units to do the same even though they require modification ". Confirmation in the Regulation of Menpan R.B. above, becomes one of the legal bases in modifying the Service Model, either in the form of something newly discovered or a modification of an existing model. This model was then popularized under the name Public Service Innovation by implementing the Public Service Innovation Information System (SiNoviK) as regulated in Chapter I (letter "c") Number 31 of 2014 concerning Guidelines for Public Service Innovation, which consists of:

1. SiNoviK was developed by the Ministry of Administrative Reform and Bureaucratic Reformation which is supported by a public service innovation network to document and disseminate knowledge in good practice as a reference;

2. The documentation lists the parts of innovation, implementation strategy, resistance and learning of each innovation so that it is hoped that it can help other agencies or regions in formulating ideas into new innovative actions;

3. The Ministry of State Apparatus Empowerment and Bureaucratic Reformation undertakes efforts to document public service innovation knowledge. 
The concept of innovation in the delivery of public services in Depok City is intended to restore the image of the government, which must be present to provide quality services to the public, as stated by Denhard "Serve Citizens, Not Customers: The public interest is the result of a dialogue about shared values. rather than the aggregation of individual self-interests. Therefore, public servants do not merely respond to the demands of "customers," but rather focus on building relationships of trust and collaboration with and among citizens " (Denhardt \& Denhardt, 2000).

Denhard's opinion shows that the implementation of public services provided to the community, not just customers, but also the community as service recipients in their capacity as citizens (Denhardt \& Denhardt, 2000). For this reason, it is necessary to understand that Service Innovation in the public sector is oriented towards aspects of improving Service Delivery starting from input, process and output, as well as outcomes in accordance with the vision, mission of providing public sector services which are used as evidence that the government is present in the midst of the people providing services that are effective, efficient and of high quality in accordance with the prevailing laws and regulations. Service innovation should be at the core of all service activities in the public sector (Julier, 2020; Vickers et al., 2017), because by innovating in Public Implementation Services, it will bring about service performance that has so far been judged by a number of circles to have not realized services according to the expectations and / or desires of the community (Chen et al., 2020; Julier, 2020; Vickers et al., 2017). Thus, innovation means increasing responsiveness to the expectations of citizens and the needs of service users, through efficient and effective services (quality service).

\section{Method}

This study was designed using a qualitative research methodology with a descriptive approach. Descriptive Qualitative Analysis in this study is intended to analyze and describe and interpret data based on the research object. Morse who is then quoted by Creswell explains the characteristics of the problematic qualitative research that:

Characteristics of a qualitative research problem are: (a) the concept "immature" due to a conspicuous lack of theory and previous research; (b) a notion that the available theory may be inaccurate, inappropriate, incorrect, or biased; (c) a need exists to explore and describe the phenomena and develop theory; or (d) the nature of the phenomenon may not be suited to quantitative measures (Creswell, 2009).

Based on the Characteristics of a qualitative research problem by Morse above, Creswell describes that: "Qualitative research is defined as a process of inquiry to understand social problems based on a holistic (complete) description formed by words, reports the views of the informants in detail and is prepared against a natural setting" (Creswell, 2009).

\section{Result and Discussion}

\section{The complexity of licensing and non-licensing services}

Public Understanding of the Implementation of Licensing Services 
Public Service Providers have an obligation to achieve community (customer) satisfaction. The community as service users has the right to get good and appropriate services based on existing needs (Adrian Smith \& Stirling, 2016). Related to this, innovation is needed to change the mindset of the community, both on systems and procedures as well as service requirements as well as on regulations related to public service delivery. System and Procedure are two things that are inseparable from the implementation of Public Services which are manifested in Minimum Service Standards and Standard Operating Procedures (A Smith, 2014). Of the 100 Community Informants associated with Licensing Services at DPMPTSP Depok City, there are 60 Community Informants who do not clearly understand the Service System and Procedure. In addition, they also find it difficult due to the mismatch of information conveyed by the Servant Apparatus with reality. The community also feels the complexity associated with the requirements for using recommendations, such as the Neighbors Approval Permit related to the needs of the business to be established. Starting from the Certificate of Place Ownership, the Neighbors Permit, to the Recommendation Letter from the relevant Office. Likewise, it also takes time from one place to another.

Since 2017, DPMPTSP Depok City has implemented 2 types of online-based services. The types of services referred to are: 1. Trading Business License (SIUP) and 2. Company Registration Certificate (TDP). Regarding the types of services above, it is still limited to registration (registration), while filing is still done manually and can be sent via online transportation. Regarding what the community feels, is one of the indicators that must be improved by DPMPTSP on the implementation of an online-based licensing service system. Another difficulty felt by the community towards licensing services in the city of Depok is the apparatus' indifference to customers. Apparatus awareness related to duties and functions is still very minimal (Walker et al., 2002).

Regulations related to the Implementation of Licensing Services and Licensing Service Innovations in Depok City DPMPTSP should be understood by the Service User Community. The intended regulations are: 1) System and Procedure for Providing Licensing Services (described in the previous section), 2) Obligations and Rights of the Community towards Licensing Services, 3) Obligations of Licensing Service Providers, and 4) Prohibition of Licensing Service Providers (Apparatus) (Minister of Bureaucracy Republic of Indonesia's Regulation Number 15 Year 2017).

\section{Public Service Innovation Model}

Referring to the Research Results and Discussion as stated above, the Public Service Innovation Model recommended as a result of this study includes; Local Government Hearing, System Reconstruction in Public Service Institutions through (1) Internal and External dimensions consisting of sub dimensions; Service Standards and Procedures, Service Requirements, Dynamics and Complexity of Services and Regulations, meanwhile, (2) Organizational Characteristics include; Planning, Leadership and Human Resources, and Organizational Culture, while (3) Organizational Strategy can be seen in sub dimensions; Public Service Innovation, Organizational Collaboration, and Organizational Learning (Ashworth, 2010). It is necessary to note that the three dimensions as stated above will not be 


\section{Macrothink}

Journal of Public Administration and Governance

ISSN 2161-7104

2020, Vol. 10, No. 4

achieved as expected if they are not supported by a Mental Revolution for the Organizing Apparatus. The success of the Mental Revolution for the Organizing Apparatus greatly depends on the political will, the official who has the authority to make decisions (Centre for Public Service Innovation, 2004). For this reason, the Competent Authority as stated above, is highly determined by the highest knowledge and tactics, so that they are wise in deciding, fair in sharing, and responsive to the demands of change, and accommodating to the suggestions and opinions of others. For more details, it can be seen in the following image.

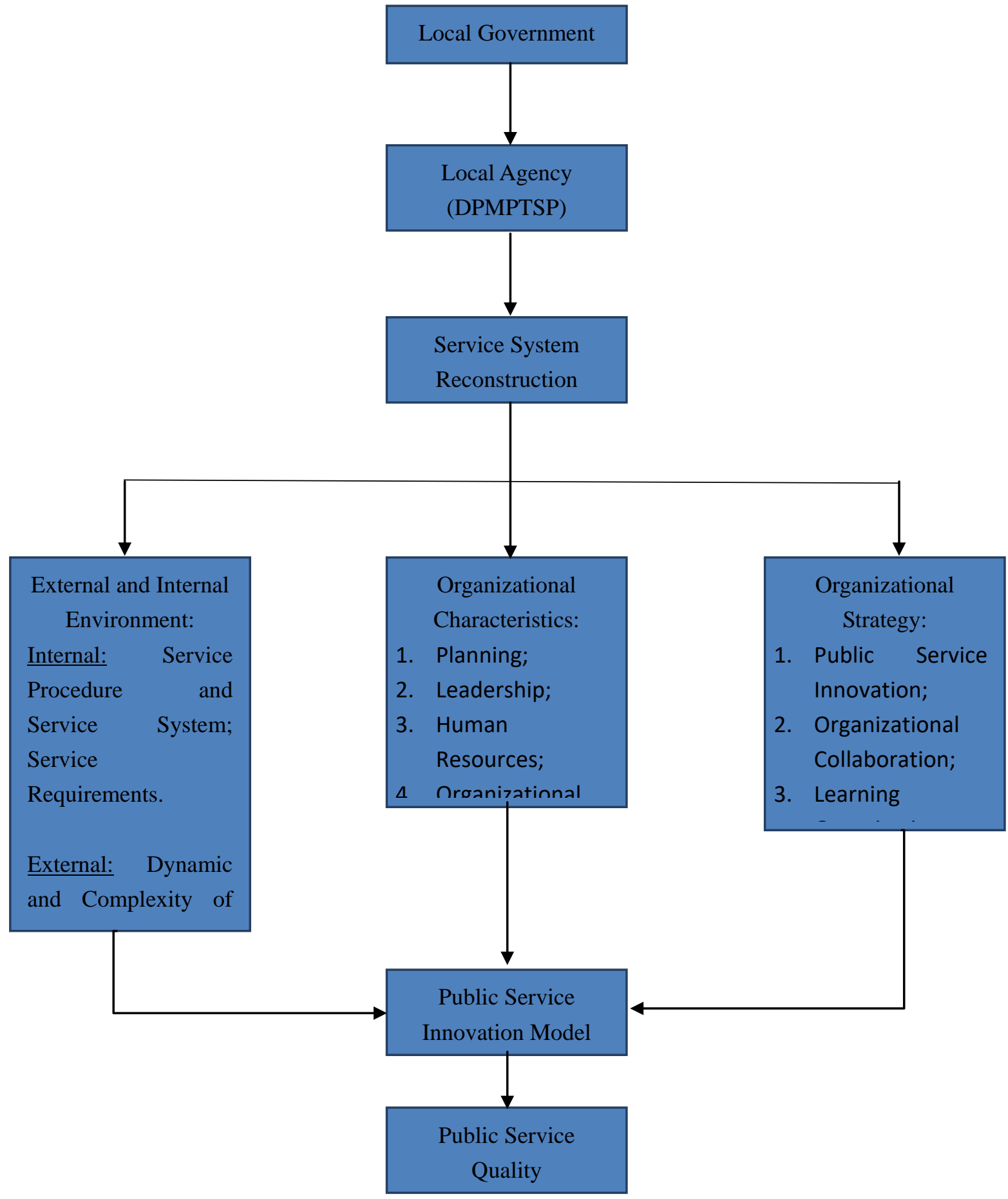

Figure 1. Public Service Innovation Model 
Source: Managed by Author, 2020

\section{Conclusion}

Organizational environment, both internal and external, has an important role in Public Service Innovation at DPMPTSP Depok City. Internally, several categories are inseparable parts of the service delivery process, such as Licensing and Non-licensing Service Systems and Procedures, which are still convoluted. Public Complaint Handling has not been accommodated and has not been followed up appropriately. The Service Apparatus Behavior has not resulted in Wholehearted and Generous Service. The Service Promise as stated in the Service Notice has not materialized properly. Standard Operating Procedures (SOPs) are not fully based on community needs to create new values and are "innovative" in nature. Sanctions for service personnel according to the SOP have not been implemented properly and there are no regulations related to Apparatus Ethics in providing services to the people of Depok City. If the Service System and Procedure as well as Service Notices have been implemented based on appropriate Standard Operating Procedures (SOP) and the support of Community-based Service Apparatus Ethics to realize the quality and satisfaction of the Community as Service Users, then this will become part of the Innovation process. To realize Licensing and Non-licensing Service Innovations at DPMPTSP Depok City, accommodating the involvement of each OPD in one place so that the Investment Service as a One Stop Integrated Service characterizes Service Integrity starting from process, input to output, including integration of budgeting aspects. Strengthen collaboration between organizations to support the realization of Service Innovations.

\section{Reference}

Ashworth, R. (2010). Public Service Improvement. Oxford University Press.

Centre for Public Service Innovation. (2004). From Red Tape to Smart Tape. In Future Watch.

Chen, J., Walker, R. M., \& Sawhney, M. (2020). Public service innovation: a typology. Public Management Review. https://doi.org/10.1080/14719037.2019.1645874

Creswell, J. W. (2009). Research design: Qualitative, quantitative, and mixed methods approaches (3rd ed). Research Design Qualitative Quantitative and Mixed Methods Approaches. https://doi.org/10.1016/j.math.2010.09.003

Denhardt, R. B., \& Denhardt, J. V. (2000). The new public service: Serving rather than steering. Public Administration Review. https://doi.org/10.1111/0033-3352.00117

Julier, G. (2020). Public Sector Innovation. In Economies of Design. https://doi.org/10.4135/9781529714418.n8

Smith, A. (2014). Grassroots innovation movements: Challenges and contributions. Journal of Cleaner Production, 63, 114-124. https://doi.org/10.1016/j.jclepro.2012.12.025

Smith, Adrian, \& Stirling, A. (2016). Grassroots Innovation \& Innovation Democracy. In STEPS Centre. 


\section{Macrothink}

Journal of Public Administration and Governance ISSN 2161-7104 2020, Vol. 10, No. 4

Vickers, I., Lyon, F., Sepulveda, L., \& McMullin, C. (2017). Public service innovation and multiple institutional logics: The case of hybrid social enterprise providers of health and wellbeing. Research Policy. https://doi.org/10.1016/j.respol.2017.08.003

Walker, R. M., Jeanes, E., \& Rowlands, R. (2002). Measuring innovation - Applying the literature-based innovation output indicator to public services. Public Administration. https://doi.org/10.1111/1467-9299.00300

\section{Copyright Disclaimer}

Copyright for this article is retained by the author(s), with first publication rights granted to the journal.

This is an open-access article distributed under the terms and conditions of the Creative Commons Attribution license (http://creativecommons.org/licenses/by/4.0/). 